\title{
THE RELATIONSHIP BETWEEN HUMAN CAPITAL INVESTMENT, NON- PERFORMING FINANCING AND PROFITABILITY Hasan Mukhibad $^{1 *}$, Indah Anisykurlillah ${ }^{2}$, Prabowo Yudo Jayanto ${ }^{3}$ \\ ${ }^{1,2,3}$ Accounting Department, Economics Faculty, Universitas Negeri Semarang, Indonesia. \\ Email: ${ }^{1 *}$ hasanmukhibad@mail.unnes.ac.id, ${ }^{2}$ indah_anis@mail.unnes.ac.id, ${ }^{3}$ yudho@ mail.unnes.ac.id
}

Article History: Received on $18^{\text {th }}$ January 2020, Revised on $15^{\text {th }}$ February 2020, Published on $29^{\text {th }}$ February 2020

\begin{abstract}
Purpose of the study: This research aims to identify the influence of good corporate governance (GCG) mechanisms and human capital investment (HCI) on non-performing financing (NPF) and profitability. In addition, we examine the relationship between NPF and profitability.
\end{abstract}

Methodology: The research samples are commercial Islamic banks in Indonesia (13 banks) that were determined by using a purposive sampling method. The data are collected from the banks' financial statements and GCG reports, from 2012 to 2016. Structural Equation Modeling (SEM) was employed to analyze the data.

Main Findings: Our study shows that the number of directors a bank has significantly affected NPF but does not affect profitability, while the size of the independent Board of Commissioners (BoC) has a significant influence on NPF and profitability. Sharia Supervisory Board also has a role in improving profitability. HCI has a significant effect on profitability, but it does not affect NPF.

Applications of this study: Islamic banks are urged to improve their implementation of GCG, especially for their ratio of independent commissioners and $\mathrm{HCI}$ expenditure. Independent commissioners and $\mathrm{HCI}$ are able to reduce the level of NPF and improve performance. HCI expenditure should be viewed as an investment by the bank, and not as a cost. Investment in $\mathrm{HCI}$ is proven to improve profitability.

Novelty/Originality of this study: The use by researchers of the HCI variable to influence NPC is still limited. The reason is that the main source of a bank's income is from financing (loans), so the highest risk for the bank is NPF. To reduce NPF, the bank's employees must have the ability to manage risk.

Keywords: Human Capital Investment, Non-Performing Financing, Profitability, Corporate Governance.

\section{INTRODUCTION}

Islamic financial institutions in Indonesia have experienced rapid growth (Anisykurlillah \& Mukhibad, 2016). Indonesian bank data show a $44 \%$ growth in the assets of Islamic banks (Purbaningsih, 2014). This high asset growth was attributed to the 52.2\% growth in financing (Purbaningsih, 2014). The growth of Islamic banks' assets in Indonesia is also supported by an increase in the number of branches.

However, Islamic banks in Indonesia have a great number of non-performing loans. The non-performing financing ratio of sharia banks, as of October 2017, was $4.12 \%$ and NPF is higher than the ratio of non-performing loans in conventional banks (Huda, 2012). The Treasurer of the Association of Indonesian Sharia Banks (Asbisindo) stated that the high levels of NPF in Islamic banks are caused by external factors (macroeconomic) and internal (human resources who are unable to perform financial risk management).

Many researchers have described the causes of NPF in banks. The determinants used to explain NPF are internal and external factors (macroeconomic). Laryea et al., (2017) uses the variable of net interest margin (NIM), gross domestic product (GDP), inflation, size, bank credit advanced (ADEP), capital adequacy ratio (CAR) and the asset concentration of the banking industry to explain NPF of banks in Ghana. Andriyan (2010) uses the percentage of managerial ownership, the proportion of outside directors, Board of Directors, size and age to explain the NPF of rural banks in Indonesia. Al-wesabi \& Ahmad (2013) use leverage and liquidity as internal variables, and the inflation rate and interest rate to explain NPF. Alandejani \& Asutay (2017) use risk-weighted assets to total assets, GDP, country characteristics (oil or non-oil), Return On Equity (ROE), NIM, efficiency score, and financing characteristics to explain NPF.

Previous studies have not used HCI as a variable, even though it is strongly suspected to have an effect by reducing NPF, but there is very little research that proves the effect of HCI on profitability. The use of HCI as a predictor variable for reducing NPF is due to the increase of NPF issued by Islamic banks, which has been caused by their employees' inability to manage risk. HCI is an expenditure made by banks to improve their employees' skills. Thus, HCI is strongly associated with NPF. In addition, studies that explain Islamic banks' NPF are still rare.

In addition, besides the effect HCI has on NPFs' decline, HCI will affect bank profitability. HCI will enhance the employees' ability to do their jobs. The financing section will be more effective in finding funds by updating the methods used to market the bank's products. The operational section will complete its tasks effectively and efficiently. Furthermore, it will comprehensively improve bank performance. 
In this research, we developed the NPFs' size as one measure of financial performance. HCI causes employees to be more effective in their work. The use of NPF is based on the reason that financing is a bank's main source of income and a key indicator for assessing the bank's ability to act as an intermediary institution. Islamic banking is mainly engaged in relationship lending (Nawaz, 2017). Moreover, Ongena \& Smith (2001) stated that a good relationship between a bank and its borrowers is very important to create corporate value in the long run. Additionally, ROA and ROE measurements could be biased, because they do not separate the main income from the non-primary income. In developing our hypotheses, we use NPF, ROE and ROA as variables for measuring financial performance.

\section{LITERATURE REVIEW}

The resource-based theory is a theory that is used to develop strategic management practices. This theory believes that a company will achieve victory if the company has superior resources. Companies can have a variety of resources, in the form of physical, financial, information and human resources (HR) (Pivac, Barać, \& Tadić, 2017). In the view of the resource-based theory, a company will have good financial performance if the company owns, controls and utilizes important strategic assets (tangible and intangible assets).

Lately, researchers have developed the resource-based theory of corporate competitive advantage by including human capital as the main factor explaining why some companies are superior to others (Acedo, Barroso, \& Galan, 2006). The resource-based theory states that the heterogeneity of the distribution of valuable resources in companies, such as human resources, and the differences in corporate resources, is what causes differences in companies' performance (Barney, 1991). In addition, this human capital will have an impact on improving the employees' morale and motivation (Bayraktar \& Șencan, 2017).

The implication of this theory is that banks are required to invest in the development of their human resources through education and training. Du, Yin, \& Hou (2018) and (Lips, 2013) agree that employee education is an important attribute of human capital. Education and training programs will have a positive impact on the knowledge and ability of employees to analyze financial problems so that financing is provided to customers and businesses at the right level of profit-sharing/margins. This should minimize financing that is not/less productive and will further increase profitability. In addition, the distribution of appropriate financing will reduce the risk of NPF.

\section{Human Capital Investment}

$\mathrm{HCI}$ is an important resource for companies because this is a unique resource and it is difficult for other companies to emulate. This uniqueness is because HCI is aimed at increasing the expertise, knowledge, skills, abilities, attitudes, and emotional intelligence of banks' employees (Pivac et al., 2017). So HCI is a strategic resource for banks in creating a competitive advantage.

$\mathrm{HCI}$ in banks is needed for the creation of competitive advantage. Banks face large risks, intense competition and the rapid renewal of their products. Banks need to have a competitive advantage to support the sustainability of their business and beat the competition. Compared to conventional banks, Islamic banks face greater challenges.

Islamic banks are exposed to risk because they use a profit-sharing system that means the banks may have to bear the losses from businesses run by their customers. In addition, Sharia banks run the risk of failing in their compliance. In all of their operations, Islamic banks must implement Islamic laws on policy, strategy, marketing, products, and overall banking operations, so they can offer solutions to customers' financial problems without violating Islamic law (Nawaz, 2017).

Islamic banks find it very difficult to compete in countries that have dual banking systems, such as in Indonesia, Malaysia, and other non-Islamic countries. Islamic banks find it increasingly difficult to operate successfully because they have very small economies of scale. Our conclusion is that HCI is very necessary for Islamic banks, to guarantee the continued existence of these banks, and at the same time letting them operate in accordance with Islamic law.

\section{Hypothesis Development}

The resource-based theory states that a company's performance depends on the structure of the company's assets. The structure of its assets can be divided into tangible assets and intangible assets. Human capital investment is corporate expenditure used to acquire, develop or improve the ability of employees in carrying out their duties. Greater employee ability will result in better decision making and improvements in the services offered to consumers. Human capital investment, in the form of expenditure on the education and training of its employees, will improve the financial performance of an Islamic bank (Asri, 2017).

Tadić, Barać, \& Plazonić (2015) have proven empirically that corporate expenditure for employee development (Human Capital Investment) increases companies' performance in Croatia and enhanced their competitive advantage. Nawaz (2017), in his research, found that HCI has a positive influence on a bank market performance. The education and training costs incurred by the bank will increase the ability, knowledge, skill, and attitude of its employees and will further increase their productivity. This condition will have a positive impact on banks' performance. The results of this 
study are supported by Asri, (2017) who found that funding the training and education of employees was able to increase a bank's.

\section{H1: HCI has a positive influence on bank profitability.}

Islamic banks require employees to have knowledge of both banking and Sharia law (Nawaz, 2017). Employees who are competent in both will be better able to analyze and make financial decisions, which improve the revenue generation and ensure compliance with Sharia law. To improve the abilities of employees, banks can conduct training, education and other improvements. In his study, Al-ghazawi (2012) recommended empowering HR managers with the tools and techniques needed to improve their role and increase their impact on the overall performance of the banks. Thus the following hypothesis is developed:

\section{H2: HCI has a negative influence on NPF}

The agency theory states there will be a conflict between a manager, as the agent, and the shareholders, as the principals. This conflict arises because the agent has a tendency to emphasize his/her own interests rather than the interests of the shareholders. Evidence of this conflict can be seen in the behavior of the agent regarding earnings management, fraud, and other acts of cheating. In an effort to reduce this conflict, the shareholders should implement good corporate governance (Arouri, Hossain, \& Muttakin, 2014). Accountability, which is one of the principles of corporate governance, could reduce the information asymmetry between the agent and the principals, which is the main source of agency conflict.

The implementation of GCG has an effect on performance. Some studies, such as those by Cheema \& Din (2013); Rehman, Ramiz Ur; Mangla (2010), and Heenetigala (2011) indicate a significant relationship between GCG and performance. The corporate governance framework encourages the accountability of the resources (Choudhury \& Alam, 2013). Corporate governance can improve the effectiveness of the monitoring undertaken by the Board of Commissioners (BoC). As a result, the Board of Directors (BoD) will improve its performance and this will further impact on improving the company's financial and social performance.

The GCG mechanism has many measurements as a research variable. One measurement of the GCG mechanism is the number of directors (size). The directors have an obligation to directly manage the company's resources, to realize the company's objectives. The bigger that the company's resources are means the greater is the abilities that the directors need to possess, which can be seen by the impact of their decisions on improvements in performance. The number of directors will have an impact on the effectiveness of the company's management and its decision-makers, and further impact the improvement of the company performance (Nawaz, 2017; Dixon \& Stratling, 2013). In a study of 47 Islamic banks in various countries, Nawaz (2017) found that the size of the Board has a positive influence on the market performance of Islamic banks. Meanwhile, Andriyan (2010) has used a rural bank in Indonesia as a research object and found that the number of directors affected the bank's performance, as measured by NPF and ROA.

H3: The size of the BoD has a positive influence on profitability.

H4: The size of the BoD has a negative influence on NPF.

GCG mechanisms can be measured by the size of the BoC; which acts as the shareholders and other stakeholders' representatives to monitor the performance of the $\mathrm{BoD}$. The owners of a company have a tendency to appoint directors who are able to fulfill the interests of the controlling owners Rehman \& Mangla, 2010) and who would ignore the interests of other stakeholders. Consequently, independent commissioners are needed to control the management of the company (Pathan \& Faff, 2013). The BoC is required to ensure the interests of all the stakeholders have been met by the BoD.

H5: The ratio of the independent $\mathrm{BoC}$ has a positive influence on profitability.

H6: The ratio of the independent $\mathrm{BoC}$ has a negative influence on NPF.

GCG mechanisms in Islamic entities differ from those in conventional entities, due to the presence of the Sharia Supervisory Board (SSB). The SSB exists to ensure that banks operate in accordance with Islamic law. The SSB also has a duty to provide consulting services when assessing new products, which will be offered by the banks, for their compliance with Islamic law. In providing this consultation, the SSB offers advice on compliance with Sharia principles but also pays attention to the market needs. The products should comply with Islamic law, and be marketable. This is evidenced by Nomran, Haron, \& Hassan (2017) who found that SSBs have a positive influence on banks' performance. Mollah \& Zaman (2015) found that an SSB has a positive effect on performance if it performs a supervisory function, and has no impact on performance if it only functions as a consultant. The large SSBs are more efficient at monitoring and advising than small SSBs (Quttainah \& Almutairi, 2017). Consequently, this suggests that increasing the size of SSBs should improve management behavior and organizational performance (Quttainah \& Almutairi, 2017). In addition to improving profitability, the size of an SSB also has a positive relationship with the market performance of Islamic banks (Nawaz, 2019).

H7: The size of SSBs has a positive influence on profitability. 
H8: The size of SSBs has a negative influence on NPF.

NPF is the main problem faced by banks. The main income of a bank is the revenue it gains from making loans, so the performance of its loans greatly affects the bank's profitability. Purbaningsih (2014), Setyawati, Suroso, Suryanto, \& Nurjannah (2017) and Laryea et al., (2017) have all proved empirically that NPF levels have a negative effect on ROA and banks' ROE. Thus the following hypothesis can be developed:

H9: NPF has a negative effect on profitability (ROA and ROE).

\section{METHODOLOGY}

The population of this study is the commercial Islamic banks in Indonesia with an observation period from 2012 to 2016. There are 13 commercial banks in Indonesia. The research sample is determined by a purposive sampling method (banks that present their HCI expenditure).

The number of directors and members of the relevant, for each bank, are noted. The number of independent commissioners is found by taking the number of independent commissioners and dividing this figure by the total number of commissioners. NPF is measured from the ratio of non-performing financing compared to total financing. HCI is measured by salary, recruitment, and educational costs. Profitability is measured by both ROA and ROE.

The data were analyzed using the SEM with a WarpPLS test. This test device is used because SEM can perform complex tests on models. The acceptance rate of hypothesis based on an error rate of $5 \%$ and $10 \%$.

\section{RESULTS/FINDINGS}

Descriptive analysis results for each variable used are as follows:

Table 1: Descriptive analysis

\begin{tabular}{lllll}
\hline Variables & Mean & Max & Min & St. Dev \\
\hline BoDsize & 4.4762 & 7.0000 & 3.0000 & 0.9687 \\
\hline SSB size & 2.2857 & 4.0000 & 2.0000 & 0.5078 \\
\hline Independent BoC & 0.6762 & 1.0000 & 0.5000 & 0.1408 \\
\hline NPF & 3.3687 & 9.8177 & 0.2006 & 2.2767 \\
\hline HCI & 0.0008 & 0.0039 & 0.0001 & 0.0008 \\
\hline ROA & 0.4682 & 2.3786 & -1.3448 & 0.6787 \\
\hline ROE & 3.6591 & 17.9311 & -10.4501 & 5.1597 \\
\hline
\end{tabular}

Table 1 show that the variables that have the highest range are ROE and NPF. The average of NPF is quite high, ie. $3.37 \%$ and the average of ROE is $3.69 \%$. NPF of the bank is $9.82 \%$ and its ROE is $-10.45 \%$. This NPF is more than $5 \%$ and indicates that the bank's financing is poor.

The result of the SEM test using a WarpPLS tool shows the following result:

Table 2: Model fit and quality indices

\begin{tabular}{lll}
\hline Indicator & Value & $\mathbf{P}$ \\
\hline Average path coefficient (APC) & 0.165 & 0.0560 \\
\hline Average R-squared (ARS) & 0.337 & 0.0020 \\
\hline Average adjusted R-squared (AARS) & 0.232 & 0.0200 \\
\hline Average block VIF (AVIF) & 1.797 & acceptable if $<=5$ ideally $<=3.3$ \\
\hline Average full collinearity VIF (AFVIF) & 3.068 & acceptable if $<=5$ ideally $<=3.3$ \\
\hline
\end{tabular}

Table 2 shows that the AVIF score is 1.797 and the AFVIF score is 3.068. Both of these scores are below five, and even below 3.3. This suggests that the model is ideal and has been accepted. Thus the model can be used for testing the hypotheses.

The alpha score and significance of each hypothesis is shown in the following table:

Table 3: Hypotheses Test Results

\begin{tabular}{llll}
\hline Hypothesis & Beta & Sig. & Conclusion \\
\hline H1: HCI has a positive influence on bank profitability & 0.34 & $<0.01$ & Ha Received \\
\hline H2: HCI has a negative influence on NPF & 0.02 & 0.44 & Ha Rejected \\
\hline H3: The size of the bodies a positive influence on profitability & 0.07 & 0.31 & Ha Rejected \\
\hline
\end{tabular}




\begin{tabular}{llll}
\hline H4: The size of the BoD has a negative influence on NPF. & 0.23 & 0.05 & Ha Received \\
\hline $\begin{array}{l}\text { H5: The ratio of the independent BoC has a positive influence } \\
\text { on profitability. }\end{array}$ & 0.18 & 0.10 & $\begin{array}{l}\text { Ha Received } \\
\text { (Sig 10\%) }\end{array}$ \\
\hline $\begin{array}{l}\text { H6: The ratio of the independent BoC has a negative influence } \\
\text { on NPF. }\end{array}$ & 0.17 & 0.10 & $\begin{array}{l}\text { Ha Received } \\
\text { (Sig 10\%) }\end{array}$ \\
\hline H7: The size of SSBs has a positive influence on profitability & 0.37 & $<0.01$ & Ha Received \\
\hline H8: The size of SSBs has a negative influence on NPF. & 0.11 & 0.21 & Ha Rejected \\
\hline H9: NPF has a negative effect on profitability & 0.14 & 0.16 & Ha Rejected \\
\hline
\end{tabular}

The number of directors has a significant and positive influence on NPF. The directors have a duty to ensure the company's resources are managed effectively and efficiently, to achieve the company's goals. Based on the stakeholder theory, the purpose of a company is to fulfill the interests of its stakeholders in both the short and long term. This means the directors have a duty to meet the interests of the stakeholders. One thing that can increase the fulfilment of the stakeholders' interests a low rate of NPF. A high rate of NPF can reduce a bank's earnings and its turnover of capital. Nevertheless, the results of this study prove empirically that the number of directors has a positive impact on NPF. If a bank only has a few directors, they may well be less effective in supervising the loans made by the bank, thus causing a high rate of NPF. The results of this study reinforce the opinion of Andriyan (2010), who stated that the size of a body causes more difficulties in coordination and communication between the members of the BoD.

The results also proved empirically that the number of directors has no influence on banks' profitability. These findings reinforce the findings of Beiner, Drobetz, Schmid, \& Zimmermann, (2003) who found that the number of members on above did not affect that firm performance, as measured by ROA and ROE. These findings indicate that the role of directors in improving the performance of Islamic banks is still low. The directors have not worked effectively to improve their bank's performance. In addition, the results rejected the findings of Nawaz (2017) which found that the size of a BoD had a positive influence on the market performance of the bank, and the findings of Andriyan (2010) who found that the size of a BoD had an influence, but a negative one, to ROA.

The ratio of independent commissioners has a positive and significant relationship to NPF and profitability, at the level of $10 \%$ significance. The commissioners are the stakeholders' representatives and monitor the performance of the directors. Non-independent commissioners represent the minority owners and stakeholders and control the directors. The independent commissioners also represent the shareholders. Centralized ownership often selects a management group that will fulfill the interests of the controlling shareholders and has a tendency to ignore the interests of the minority owners and the other stakeholders. Thus independent commissioners are required to ensure that the directors also meet the interests of the minority shareholders and other stakeholders, as well as those of the owners.

The size of the SSB has no relationship with NPF, but the size of the SSB has a positive effect on its bank's profitability. Each SSB has the task of monitoring the bank and consulting with it about how it is run in accordance with Islamic law. Islamic law must be obeyed by the bank within its operations. The size of SSB greatly affects its effectiveness in performing its duties. When consulting with its bank, the SSB not only pays attention to Sharia law but also to the response to products offered by the bank. The SSB will approve products that comply with Sharia law and may prove profitable, thus increasing the bank's profitability. For that, each SSB needs members who understand Islamic law and banking. Nevertheless, the SSBs have not had much success in reducing the banks' NPF. NPF increases if the SSB's advice to the bank is not financially sound. The results of this study confirm the findings of Nomran et al., (2017); Mollah \& Zaman (2015); Quttainah \& Almutairi (2017) and Nawaz (2017) who all found that the size of the SSB has a positive effect on its bank's performance.

The expenditure on HCI empirically does not affect NPF, but it has a positive and significant effect on profitability. HCI undertaken by banks can increase the ability of their employees to carry out their duties, thereby increasing the bank's profitability. However, HCI funded by the banks has not been focused on improving their employees' ability to disburse credit. Bank expenditures categorized as HCI are not used to improve the employee's ability to perform credit analysis, but to improve the employee's ability to perform general operational and service tasks for the banks, in order to improve the banks' satisfaction and performance ratings. The results of this study reinforce the findings of Asri (2017), Tadić et

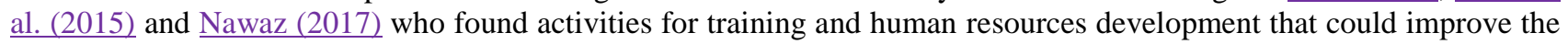
banks' performance.

This study also proved that NPF has no effect on profitability. High rates of NPF do not affect bank profitability. Although banks may have a high rate of NPF, Islamic banks in Indonesia have other income sources that can cover bank losses due to high NPF. The results of this study rejected the findings of Purbaningsih (2014) and Setyawati et al., (2017) who found that NPF had a negative effect on the bank's performance.

\section{CONCLUSION}

The number of directors significantly affects NPF, but it does not affect profitability. This identifies that the directors do not manage the bank's resources effectively and efficiently. Thus, independent BoC has a significant influence on NPF 
and bank profitability. Independent commissioners, as the stakeholders' representatives, are capable of supervising the director's performance and improving the bank's performance.

Each SSB also has a role in improving its bank's profitability. When performing its duties in providing advisory services to the directors, each SSB will evaluate the bank's compliance with Sharia principles and the market's response. This necessitates that the members of each SSB not only understand Islamic law but also economics and finance/banking.

HCI has a significant effect on profitability and does not affect NPF. HCI is undertaken by banks to improve their employee's expertise, experience, and capabilities, and let them acquire new ones. This is an investment that can provide returns and improve banks' performance. The absence of a relationship between HCI and NPF shows that employee training on creditworthiness analysis techniques and risk management still needs to be improved.

\section{LIMITATION AND STUDY FORWARD}

The information on the HCI costs for Islamic banks in Indonesia is still limited. This condition caused a limited number of samples in this study. Future researchers are recommended to use Islamic banks in other countries as the objects for research in order to obtain a larger number of samples, as that will disclose more information.

\section{ACKNOWLEDGMENT}

The authors received financial support from the Economics Faculty, Universitas Negeri Semarang for this publication.

\section{AUTHORS CONTRIBUTION}

Hasan Mukhibad contributed to the concepts, theory, and methodology of this research. These concepts were discussed with Indah Anisykurlillah and Prabowo Yudo Jayanto. This discussion resulted in better concepts, theory, and methodology. Furthermore, the research was done by the whole team, Prabowo collected the data and Hasan wrote the results of the data analysis. This paper has been reviewed by Anis.

\section{REFERENCES}

1. Abdul-rahman, A., \& Nor, S. M. (2016). Challenges of Profit-and-Loss Sharing Financing in Malaysian Islamic Banking. Malaysian Journal of Society and Space 12, 2(2), 39-46.

2. Acedo, F. J., Barroso, C., \& Galan, J. L. (2006). The Resource-Based Theory: Dissemination and Main Trends. Strategic Management Journal, 27, 621-636. https://doi.org/10.1002/smj.532

3. Al-Ghazali, M. (2012). The Impact of Investments in Human Resources Activities on the Effectiveness of Investment in Human Capital : The Case of Commercial Banks in Jordan. International Journal of Business and Social Science, 3(18), 253-261.

4. Al-wesabi, H. A. H., \& Ahmad, N. H. (2013). Credit risk of Islamic banks in GCC countries. International Journal of Banking and Finance, 10(2), 8.

5. Alam Choudhury, M., \& Nurul Alam, M. (2013). Corporate governance in Islamic perspective. International Journal of Islamic and Middle Eastern Finance and Management, 6(3), 180-199. https://doi.org/10.1108/IMEFM-10-2012-0101

6. Alandejani, M., \& Asutay, M. (2017). Nonperforming loans in the GCC banking sectors: Does the Islamic finance matter? Research in International Business and Finance, 42, 832-854. https://doi.org/10.1016/j.ribaf.2017.07.020

7. Andriyan, O. (2010). Pengaruh Mekanisme Corporate Governance Terhadap Kinerja Keuangan Bank Perkreditan Rakyat. Jurnal Akuntansi Dan Keuangan Indonesia, 7(2), 187-204. https://doi.org/10.21002/jaki.2010.11

8. Anggraeni. (2016). The Determinant of Indonesia's Islamic Rural Banking Risk Taking. International Business Management, 10(13), 2541-2546.

9. Anisykurlillah, I., \& Mukhibad, H. (2016). A Financial Report Model For Traditional Market Traders To Increase Mudharabah Financing In Baitul Maal Wattamwil (BMT). Review of Integrative Business and Economics ResearchOnline, 5(1), 219-228.

10. Arouri, H., Hossain, M., \& Muttakin, M. B. (2014). Effects of Board and Ownership Structure on Corporate Performance Evidence from GCC Countries. Journal of Accounting in Emerging Economies, 4(1), 117-130. https://doi.org/10.1108/JAEE-02-2012-0007

11. Asri, M. (2017). Effect of Human Resource on Financial Performance of Islamic Bank in Indonesia. IOSR Journal of Business and Management, 19(12), 32-35. https://doi.org/10.9790/487X-1912013235

12. Barney, J. (1991). Firm Resources and Sustained Competitive Advantage. Journal of Management, 17(1), 99120. https://doi.org/10.1177/014920639101700108

13. Bayraktar, O., \& Şencan, H. (2017). Employees’ Approaches to Human Resources from the Asset-Resource Concepts Perspective. International Journal of Business and Social Science, 8(9), 116-127. Retrieved from www.ijbssnet.com

14. Beiner, S., Drobetz, W., Schmid, F., \& Zimmermann, H. (2003). Is Board Size an Independent Corporate Governance Mechanism? (No. 89).

15. Cheema, K. U. R., \& Din, M. S. (2013). Impact of Corporate Governance on Performance of Firm : A Case 
Study of Cement Industry in Pakistan. MPRA-Munich Personal RePEc Archive, 53202(53202). https://doi.org/10.12691/jbms-1-4-1

16. Dixon, R., \& Stratling, R. (2013). Corporate Governance and Corporate Social Responsibility Disclosure : Evidence from the US Banking Sector. https://doi.org/10.1007/s10551-013-1929-2

17. Du, X., Yin, J., \& Hou, F. (2018). Auditor human capital and financial misstatement: Evidence from China. China Journal of Accounting Research, 11(4), 279-305. https://doi.org/10.1016/j.cjar.2018.06.001

18. Dzulkarnain, A. R., \& Asrori. (2017). The Effect of Financing Risk on Sharia Compliance Performance and Profitability. Accounting Analysis Journal, 6(3), 336-346.

19. Ernawati, E. (2016). Risk of Profit Loss Sharing Financing: the Case of Indonesia. Al-Iqtishad: Journal of Islamic Economics, 8(1), 101-116. https://doi.org/10.15408/aiq.v8i1.2511

20. Heenetigala, K. (2011). Corporate Governance Practices and Firm Performance of Listed Companies in Sri Lanka. Victoria University.

21. Huda, A. N. (2012). The Development of Islamic Financing Scheme for SMEs in a Developing Country: The Indonesian Case. Procedia - Social and Behavioral Sciences, 52, 179-186. https://doi.org/10.1016/j.sbspro.2012.09.454

22. Laryea, E., Ntow-gyamfi, M., Alu, A. A., Laryea, E., Ntow-gyamfi, M., \& Alu, A. A. (2017). Non-performing Loans and Bank Profitability: Evidence from An Emerging Market. African Journal of Economic and Management Studies, 7(4), 462-481. https://doi.org/10.1108/AJEMS-07-2015-0088

23. Lips, H. M. (2013). The Gender Pay Gap: Challenging the Rationalizations. Perceived Equity, Discrimination, and the Limits of Human Capital Models. Sex Roles, 68, 169-185. https://doi.org/10.1007/s11199-012-0165-Z

24. Mollah, S., \& Zaman, M. (2015). Shari' ah supervision, corporate governance and performance: Conventional vs. Islamic banks. JOURNAL OF BANKING FINANCE, 58, $418-435$. https://doi.org/10.1016/j.jbankfin.2015.04.030

25. Nawaz, T. (2017). Momentum investment strategies, corporate governance and firm performance: An analysis of Islamic banks. Corporate Governance (Bingley), 17(2), 192-211. https://doi.org/10.1108/CG-03-2016-0052

26. Nawaz, T. (2019). Exploring the Nexus Between Human Capital, Corporate Governance and Performance: Evidence from Islamic Banks. Journal of Business Ethics, 157(2), 567-587. https://doi.org/10.1007/s10551$\underline{\text { 017-3694-0 }}$

27. Norman, N. M., Haron, R., \& Hassan, R. (2017). Bank Performance and Shari'ah Supervisory Board Attributes of Islamic Banks: Does Bank Size Matter? Journal of Islamic Finance, 6(Special Issue), 174-187. https://doi.org/10.12816/0047348

28. Ogilo, F. (2016). Effects of Financial Instruments on Performance of Islamic Banks in Kenya. The International Journal of Business \& Management, 4(8), 40-45.

29. Ongena, S., \& Smith, D. C. (2001). The Duration of Bank Relationships. Journal of Financial Economics, 61, 449-475. https://doi.org/10.1016/S0304-405X(01)00069-1

30. Pathan, S., \& Faff, R. (2013). Does board structure in banks really affect their performance? Journal of Banking and Finance, 37(5), 1573-1589. https://doi.org/10.1016/j.jbankfin.2012.12.016

31. Pivac, S., Barać, Ž. A., \& Tadić, I. (2017). An analysis of human capital investments, profitability ratios and company features in the EU. 8, 167-180. https://doi.org/10.17535/crorr.2017.0010

32. Purbaningsih, R. Y. P. (2014). The Effect of Liquidity Risk and Non-Performing Financing (NPF) Ratio to Commercial Sharia Bank Profitability in Indonesia. International Proceedings of Economics Development and Research, 57-61. https://doi.org/10.7763/ipedr

33. Quttainah, M. A., \& Almutairi, A. R. (2017). Corporate Ethics: Evidence From Islamic Banks. Journal of Management \& Governance, 21(4), 815-840. https://doi.org/10.1007/s10997-016-9360-6

34. Rehman, R. U., \& Mangla, I. U. (2010). Corporate Governance and Performance of Financial Institutions in Pakistan: A Comparison between Conventional and Islamic Bank in Pakistan. The Pakistan Development Review, 49 (4 (Part II)), 461-475. https://doi.org/10.30541/v49i4IIpp.461-475

35. Setyawati, I., Suroso, S., Suryanto, T., \& Nurjannah, D. S. (2017). financial Performance of Islamic Banking better? Panel Data Estimation. European Research Studies Journal, XX(2), 592-606. https://doi.org/10.35808/ersj/661

36. Siswantoro, D. (2014). Analysis of Islamic Bank's Performance and Strategy After Spin-off as Islamic Fullfledged Scheme in Indonesia. Procedia - Social and Behavioral Sciences, 164, 41-48. https://doi.org/10.1016/j.sbspro.2014.11.048

37. Tadić, I., Barać, Ž. A., \& Plazonić, N. (2015). Relations between Human Capital Investments and Business Excellence in Croatian Companies. International Journal of Mechanical and Industrial Engineering, 9(3), 850855. 